\title{
Phenotypic Diversity of Eragrostis Wolf in Egypt
}

\author{
Sami Rabei ${ }^{1 *}$; Hasnaa Hosni ${ }^{2}$ and Ashraf Soliman ${ }^{2}$ \\ ${ }^{1}$ Botany and Microbiology Department, Faculty of Science, Damietta University, P. B. 34517, \\ New Damietta, Egypt. \\ ${ }^{2}$ Botany and Microbiology Department, Faculty of Science, Cairo University, Giza, Egypt \\ *Corresponding author: samirabei@du.edu.eg
}

\section{Abstract}

Eragrostis Wolf is considered one of the largest genera of family Gramineae (Poaceae). It is a cosmopolitan genus and represented in Egypt by 14 taxa. The species limits are often overlapping due to the wide range in variation within this genus. So, it is difficult to establish specific boundaries and diagnostic characters. The main goal of this work is to establish the limits and the diagnostic characters in the Egyptian taxa, using cluster analysis and principal coordinates analysis based on morphological characters. Interactive keys have been designed as an aid for online identification and looking for diagnostic characters. The morphological characters of Inflorescence, spikelets, panicle, glumes, palea keels and caryopsis are very important and necessary in the identification of the studied species. The results of coordinate analysis as well as UPGMA dendogram revealed that Egyptian Eragrostis species can be divided into 3 groups: group (A) includes: $E$. minor and $E$. cilianensis; group (B) includes $E$. tef, E. tenuifolia, E. sarmentosa, E. barrelieri, E. aegyptiaca and E. pilosa while group (C) includes E. aspera, E. ciliaris, E. japonica, E. lepida, E. tenella, and E. tremula. More research is needed to confirm the occurrence of several taxa in Egypt, such as Eragrostis purpurascens and $E$. nitida, which have been reported in some publications but are uncertain.

Keywords: Cluster analysis; DELTA; Gramineae; Interactive key (Intkey); Principal coordinates analysis

\section{Introduction}

Genus Eragrostis has about 406 accepted species (POWO, 2021a) distributed throughout the world, it may be found in tropical, subtropical, and warm temperate climates (Peterson \& Sánchez Vega 2007; Watson et al. 2012; POWO 2021b). However, the speciation process appears to have been most vigorous in Africa, where the genus is represented by a large number of species (Clayton \& Renvoize 1986). Africa is characterized by vigorous number of Eragrostis species that may reach 212 species followed by Americas (153 species), Australia (74 species), tropical Asia (56 species) and 51 species in temperate Asia (Peterson et al. 2010).

According to Peterson et al. (2007, 2010), Eragrostis is placed in Eragrostideae, that includes three subtribes: Cotteinae Reeder (3 genera), Eragrostidinae J. Presl (9 genera), and Uniolinae Clayton (5 genera). Peterson et al. (2010) suggested that Eragrostideae may have originated in Australia and/or Africa and subsequently spread around the globe.

The spikelets of the genus have many florets and the lemma and palea disarticulate 


\section{Sami Rabei et al.}

separately, with usually 3-nerved and unawned lemmas, paleas are longitudinally bowed-out with ciliolate keels, paniculate inflorescences, with ciliate ligules leaves (Peterson et al. 1997). Eragrostis is known for having difficult infrageneric and specific delimitation (Veldkamp 2002; Ingram 2010), the presence of glands, mode of disarticulation of the spikelet, number and size of the anthers, and the shape of the caryopses as well as some other characters are often difficult to observe and assess (Veldkamp 2002). Most of the morphological characteristics found in the caryopsis are useful in identifying species, and this information may be utilized to infer hypothetical connections among grasses (Colbry 1957; Terrell \& Peterson 1993; Boechat \& Longhi-Wagner 2003; Peterson et al. 2007). Nevertheless, the infrageneric categorization of the entire species has not been definitively addressed, although a reasonable scheme is evidently closely related to the mode of spikelet disarticulation which is remarkably diverse still, this character probably is subject to some degree of parallel evolution (Clayton \& Renvoize 1986).

The first comprehensive work of Eragrostis in Egypt is that of Täckholm et al., (1941) and Täckholm (1974), they reported 11 species viz.: Eragrostis tenella, E. ciliaris, E. japonica (E. diplachnoides), E. cilianensis, E. aegyptiaca, E. sarmentosa (E. kneukeri), E. minor (E. poaideae), E. barrelieri, E. aspera, E. pilosa and E. tremula. In addition to these species, they reported $E$. abyssinica (E. tef) as an introduced cultivated fodder plant. El Hadidi \& Fayed (1994/95 added E. lepida while Cope \& Hosni (1991) and Cope (2005, 2009), Ibrahim et al. (2016) added one more species, namely E. tenuifolia to raise the number to 14 species.

The aim of this work is to establish the limits and the diagnostic characters of Egyptian taxa of Eragrostis, using the multivariate analyses (cluster analysis and principal coordinates analysis) based on morphological characters. In addition, identification and interactive keys have to be generalized.

\section{Material \& Methods}

This study was based on the investigation of herbarium specimens kept in Cairo University Herbarium (CAI); the examined species in Appendix (1) arranged according to phytogeographical regions proposed by El Hadidi (2000). Some other data are derived from Clayton et. al. (2021). A total of 74 morphological characters were used in this study

The application of multivariate analyses in plant systematics was currently used in the classification of many taxa and presenting results in the systematic studies (Sneath and Sokal, 1973; López-Palacios et al., 2019; Hssaini et al., 2020; Kamran et al., 2020; Muhammad et al., 2021). Numerical taxonomic studies were significant for documenting the morphological characters, and several attempts have been made in this regard to the comprehension of phenetic connections in various classes of plants (Mulumba and Kakudidi, 2010; Rahman and Rahman, 2012).

One of the common programs that is used in such analysis is DELTA (Dallwitz et al. 2000 and 2010), that is used to construct keys of the taxa, and the characters were coded in DELTA format. The data are converted using the TOKEY directives file using Confor. The KEY program is used to generate the key (see Rabei \& El-Gazzar 2007; Coleman et al. 2010; Rabei 2011; Rabei \& Abdel Khalik 2012; Rabei et al. 2013).

The data Matrix is converted and generated a matrix using the distance program DIST of the DELTA software using TODIS and DIST directives file. Distances 


\section{Phenotypic Diversity of Eragrostis Wolf in Egypt}

are calculated using a modification of the Gower coefficient (Gower 1966; 1971 and 1982). Later, similarity and distance matrices are generated (Table 1 and 2 respectively).

Similarity matrix is used to make cluster analysis using Pclass (Dallwitz et al. 2000 and 2010). Two different types of Cluster analysis are used for classification purposes, namely Increment-in-sum-of-squares with flexible sorting (ISS) and Unweighted-pairgroup-average sorting (UPMGA) (Sneath \& Sokal 1973). The interactive identification key program (Intkey) is used to obtain diagnostic characters and for online identification. The DELTA files are converted to be read by INTKEY using Confor and TOINT directive file (Dallwitz et al. 2013).

Users of the PAST software may conduct PCoA and select from a variety of similarity indexes. (Hammer et al. 2001; Hammer \& Harper 2006). The distance matrix is used as input for PAST.

Principal Coordinates Analysis (PCoA), also known under the banner of Metric Multidimensional Scaling (MDS), is similar to Principal Component Analysis (PCA) in using eigenvalues to compare multivariate data, but since PCoA can use any measure of association, it can deal with different datasets that PCA could not (Zuur et al. 2007). It is inappropriate to compare continuous and discrete data since PCA is dependent on a correlations or covariance values (Zuur et al. 2007).

\section{Results:}

The dendrogram resulted from the cluster analysis based on morphological characters using Increment-in-sum-of-squares flexible sorting method (ISS) intensity "0.15" (Fig. 1), and Un-weighted group average sorting (UPGMA) method (Fig. 2) showed that the studied species are divided into three phenons at distance levels 0.321 and 0.304 . The first group (A) includes E. minor and $E$. cilianensis, the second phenon (group B) includes: E. tef, E. tenuifolia, E. sarmentosa, E. barrelieri, E. aegyptiaca and E. pilosa while group (C) includes E. aspera, E. ciliaris, E. japonica, E. lepida, E. tenella, and E. tremula. These results are confirmed by doing Principal coordinate analysis (PCoA), Fig. (3). This analysis shows separation of the studies species into 3 groups: Group (A) at high level of PCoA1, group (B) at high level of PCoA2 whereas group (C) at low level of PCoA2.

The diagnostic characters (output from Intkey) for each species are generated and they are similar to that present in the identification. Group A is charaterized by pedicels oblong and lower glume lateral veins distinct. Group B is charaterized by pedicels filiform and fertile florets free. However, Group C is charaterized by pedicels filiform and fertile florets imbricate to tip. It appears that the morphological characters of inflorescence, spikelets, panicle, glumes, palea keels and caryopsis are very important and necessary in the identification of the studied species. 


\section{Sami Rabei et al.}
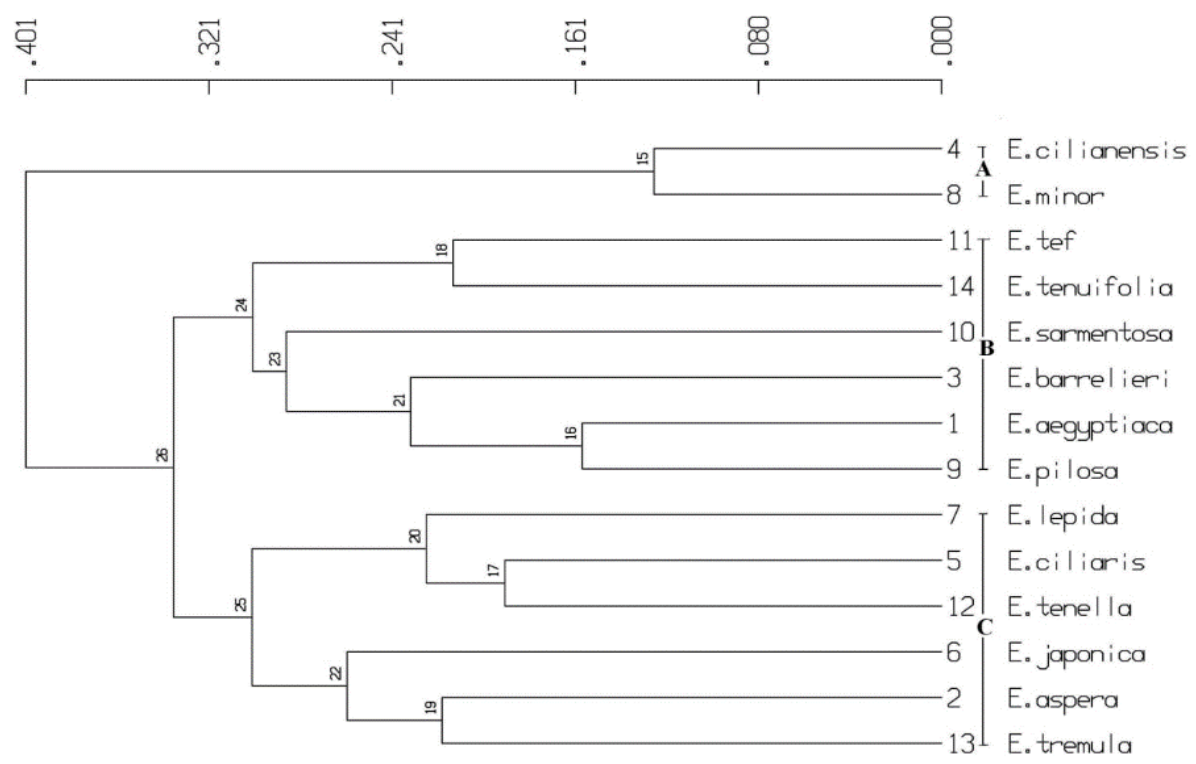

ISS FLEX 0.15

Fig. (1): A dendrogram resulted from the cluster analysis based on morphological characters using Increment-in-sum-of-squares flexible sorting method (ISS), intensity 0.15 .
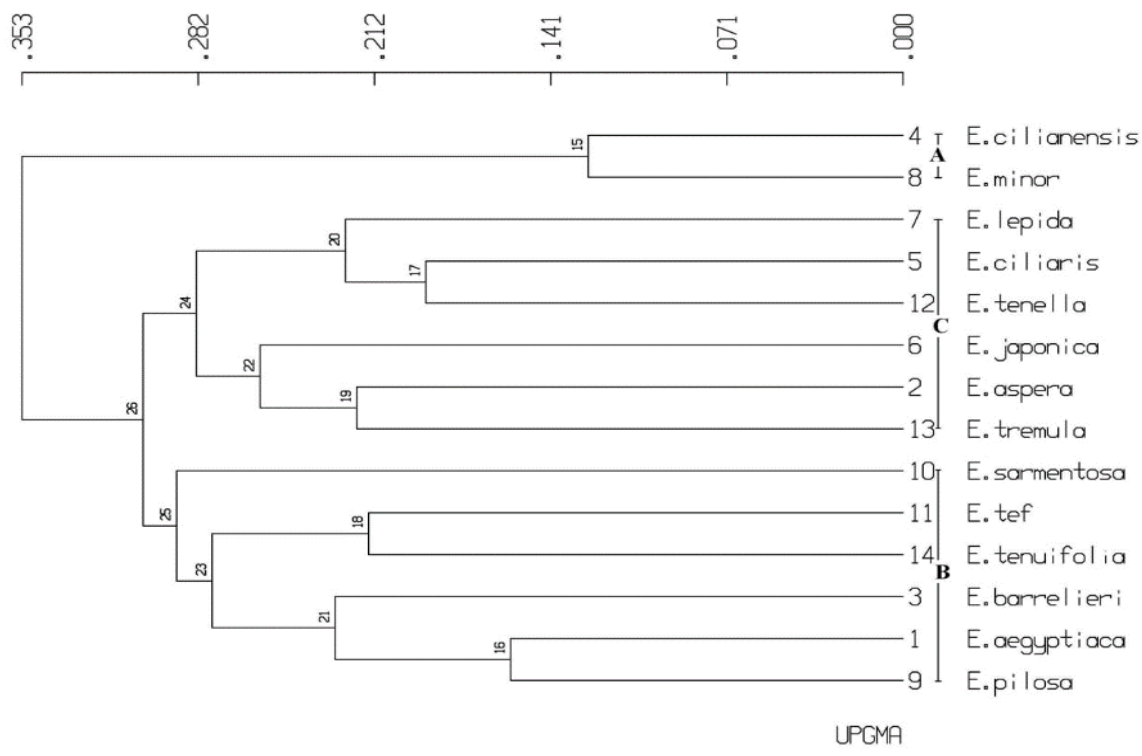

Fig. (2). A dendrogram resulted from the cluster analysis based on morphological characters using Unweighted group-average sorting (UPGMA) method. 


\section{Phenotypic Diversity of Eragrostis Wolf in Egypt.}

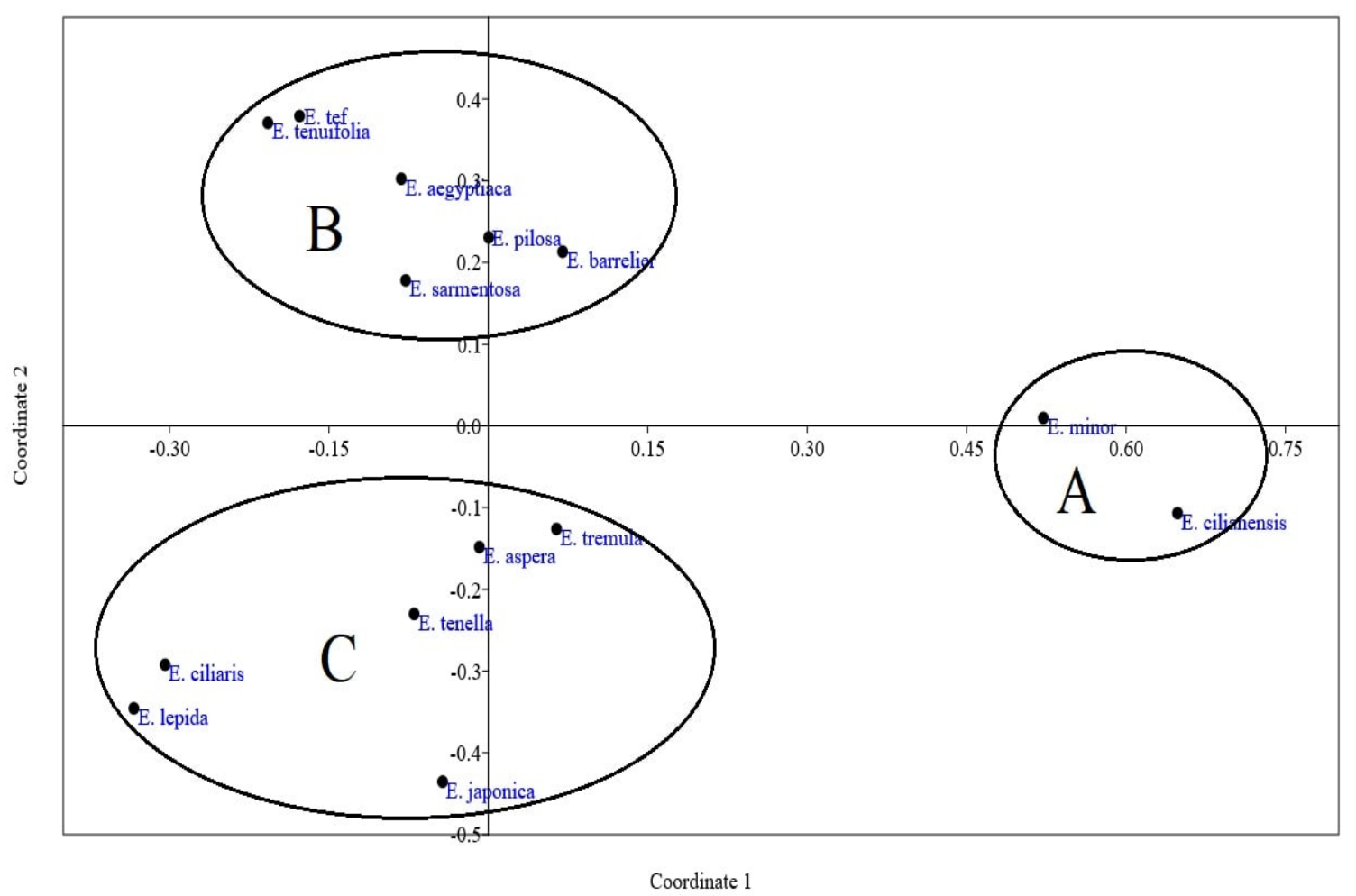

Fig. (3). Principal Coordinate analysis (PCoA) for 14 species based on morphological characters.

The similarity matrix that can be considered as a correlation coefficient among the 14 species based on their morphological traits are shown in table (1). The highest values were recorded between the 2 species that comprised group (A) of UPGMA (fig. 2) and Principal Coordinate Analysis (PCoA, fig. 3), namely $E$. cilianensis and E. minor (0.8739), followed by the values of $E$. aegyptiaca with both $E$. Pilosa and E. barrelireri, 0.8426 and 0.80022 respectively (3 species in group B of UPGMA and PCoA), followed by E. ciliaris and E. tenella (0.8087), these species were of group (C). On the other hand, the least values were recorded between different UPGMA groups: E. cilianensis (UPGMA group A) and E. lepida, E. ciliaris (both were of group C) and E. tef (Group C), 0.5525, 0.5830 and 0.5908 respectively. Moreover, the distance matrix (Table 2) confirmed these relations that the highest values in similarity gave the least distance matrices, for example the least distance matrix recorded was between $E$. cilianensis and $E$. minor (0.1261) was the highest similarity value, and so on. 


\section{Sami Rabei et al.}

Table (1). Similarity matrix (correlation coefficient) which used in cluster analysis.

\begin{tabular}{|c|c|c|c|c|c|c|c|c|c|c|c|c|c|c|}
\hline & $\begin{array}{c}E . \\
\text { aegyptiaca }\end{array}$ & $\begin{array}{c}\text { E. } \\
\text { aspera }\end{array}$ & $\begin{array}{c}\text { E. } \\
\text { barrelieri }\end{array}$ & $\begin{array}{c}E . \\
\text { cilianensis }\end{array}$ & $\begin{array}{c}\text { E. } \\
\text { ciliaris }\end{array}$ & $\begin{array}{c}E . \\
\text { japonica }\end{array}$ & $\begin{array}{c}\text { E. } \\
\text { Iepida }\end{array}$ & $\begin{array}{c}E . \\
\text { minor }\end{array}$ & $\begin{array}{c}E . \\
\text { pilosa }\end{array}$ & $\begin{array}{c}E . \\
\text { sarmentosa }\end{array}$ & E. tef & $\begin{array}{c}\text { E. } \\
\text { tenella }\end{array}$ & $\begin{array}{c}E \\
\text { tremula }\end{array}$ & $\begin{array}{c}\text { E. } \\
\text { tenuifolia }\end{array}$ \\
\hline E. aegyptiaca & 1.00000 & & & & & & & & & & & & & \\
\hline E. aspera & 0.67158 & 1.00000 & & & & & & & & & & & & \\
\hline E. barrelieri & 0.80022 & 0.72801 & 1.00000 & & & & & & & & & & & \\
\hline E. cilianensis & 0.60149 & 0.67314 & 0.70807 & 1.00000 & & & & & & & & & & \\
\hline E. ciliaris & 0.70453 & 0.71726 & 0.74061 & 0.58309 & 1.00000 & & & & & & & & & \\
\hline E. japonica & 0.65717 & 0.72425 & 0.64511 & 0.62106 & 0.73974 & 1.00000 & & & & & & & & \\
\hline E. lepida & 0.65029 & 0.70553 & 0.71211 & 0.55251 & 0.79684 & 0.64378 & 1.00000 & & & & & & & \\
\hline E. minor & 0.67064 & 0.67046 & 0.77061 & 0.87390 & 0.62157 & 0.64272 & 0.60097 & 1.00000 & & & & & & \\
\hline E. pilosa & 0.84262 & 0.73597 & 0.74414 & 0.62849 & 0.68828 & 0.71315 & 0.62355 & 0.70570 & 1.00000 & & & & & \\
\hline E. sarmentosa & 0.74599 & 0.67215 & 0.72229 & 0.61600 & 0.70029 & 0.62979 & 0.67522 & 0.66951 & 0.69393 & 1.00000 & & & & \\
\hline E. tef & 0.66749 & 0.71182 & 0.72747 & 0.59087 & 0.66437 & 0.64478 & 0.63021 & 0.59940 & 0.70280 & 0.67991 & 1.00000 & & & \\
\hline E. tenella & 0.75373 & 0.73328 & 0.75798 & 0.66275 & 0.80871 & 0.77568 & 0.75615 & 0.70786 & 0.77343 & 0.74413 & 0.66035 & 1.00000 & & \\
\hline E. tremula & 0.69886 & 0.78104 & 0.72014 & 0.68556 & 0.69746 & 0.76017 & 0.69647 & 0.71573 & 0.76064 & 0.70316 & 0.70178 & 0.73988 & 1.00000 & \\
\hline E. tenuifolia & 0.71596 & 0.71246 & 0.77276 & 0.57836 & 0.71072 & 0.64095 & 0.67179 & 0.64989 & 0.75129 & 0.70122 & 0.78575 & 0.71014 & 0.71228 & 1.00000 \\
\hline
\end{tabular}

Table (2). Distance matrix which used in PCoA analysis.

\begin{tabular}{|c|c|c|c|c|c|c|c|c|c|c|c|c|c|c|}
\hline & $\begin{array}{c}\text { E. } \\
\text { aegyptiaca }\end{array}$ & $\begin{array}{c}\text { E. } \\
\text { aspera }\end{array}$ & $\begin{array}{c}E . \\
\text { barrelieri }\end{array}$ & $\begin{array}{c}\text { E. } \\
\text { cilianensis }\end{array}$ & $\begin{array}{c}\text { E. } \\
\text { ciliaris } \\
\end{array}$ & $\begin{array}{c}\text { E. } \\
\text { japonica }\end{array}$ & $\begin{array}{c}\text { E. } \\
\text { lepida }\end{array}$ & $\begin{array}{c}E . \\
\text { minor }\end{array}$ & $\begin{array}{c}\text { E. } \\
\text { pilosa }\end{array}$ & $\begin{array}{c}E . \\
\text { sarmentosa }\end{array}$ & E. tef & $\begin{array}{c}E . \\
\text { tenella }\end{array}$ & $\begin{array}{c}\text { E. } \\
\text { tremula }\end{array}$ & $\begin{array}{c}\text { E. } \\
\text { tenuifolia } \\
\end{array}$ \\
\hline E. aegyptiaca & 0.00000 & & & & & & & & & & & & & \\
\hline E. aspera & 0.32842 & 0.00000 & & & & & & & & & & & & \\
\hline E. barrelieri & 0.19978 & 0.27199 & 0.00000 & & & & & & & & & & & \\
\hline E. cilianensis & 0.39851 & 0.32686 & 0.29193 & 0.00000 & & & & & & & & & & \\
\hline E. ciliaris & 0.29547 & 0.28274 & 0.25939 & 0.41691 & 0.00000 & & & & & & & & & \\
\hline E. japonica & 0.34283 & 0.27575 & 0.35489 & 0.37894 & 0.26026 & 0.00000 & & & & & & & & \\
\hline E. lepida & 0.34971 & 0.29447 & 0.28789 & 0.44749 & 0.20316 & 0.35622 & 0.00000 & & & & & & & \\
\hline E. minor & 0.32936 & 0.32954 & 0.22939 & 0.12610 & 0.37843 & 0.35728 & 0.39903 & 0.00000 & & & & & & \\
\hline E. pilosa & 0.15738 & 0.26403 & 0.25586 & 0.37150 & 0.31172 & 0.28685 & 0.37645 & 0.29430 & 0.00000 & & & & & \\
\hline E. sarmentosa & 0.25401 & 0.32785 & 0.27770 & 0.38400 & 0.29970 & 0.37020 & 0.32478 & 0.33049 & 0.30607 & 0.00000 & & & & \\
\hline E. tef & 0.33251 & 0.28818 & 0.27253 & 0.40913 & 0.33563 & 0.35522 & 0.36979 & 0.40060 & 0.29720 & 0.32009 & 0.00000 & & & \\
\hline E. tenella & 0.24627 & 0.26672 & 0.24202 & 0.33725 & 0.19129 & 0.22432 & 0.24385 & 0.29214 & 0.22657 & 0.25587 & 0.33965 & 0.00000 & & \\
\hline E. tremula & 0.30114 & 0.21896 & 0.27986 & 0.31444 & 0.30254 & 0.23983 & 0.30353 & 0.28427 & 0.23936 & 0.29684 & 0.29822 & 0.26012 & 0.00000 & \\
\hline E. tenuifolia & 0.28404 & 0.28754 & 0.22724 & 0.42164 & 0.28928 & 0.35905 & 0.32821 & 0.35011 & 0.24870 & 0.29878 & 0.21425 & 0.28986 & 0.28772 & 0.00000 \\
\hline
\end{tabular}




\section{Phenotypic Diversity of Eragrostis Wolf in Egypt.}

\section{Main Key}

1. Ligule membrane ciliolate

E. japonica

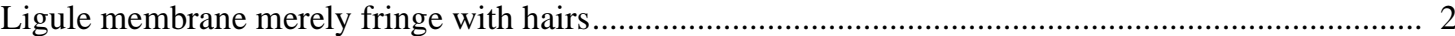

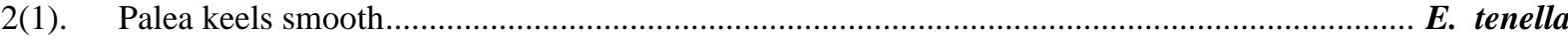

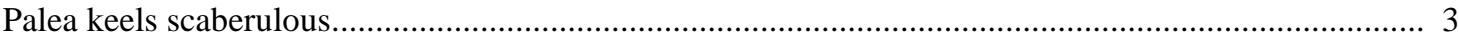

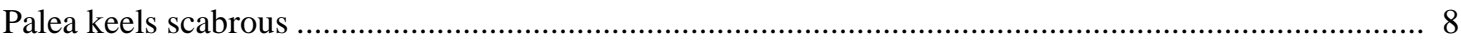

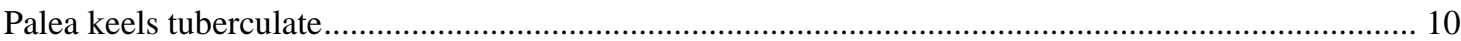

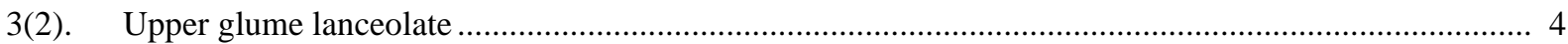

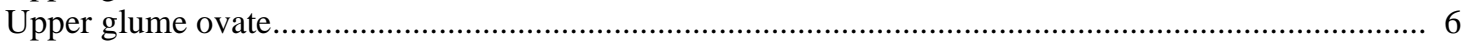

4(3). Panicle branches stiff; primary panicle branches bearing spikelets almost to base ................ E. barrelieri

Panicle branches flexible; primary panicle branches naked below ................................................ 5

5(4). Primary panicle branches not whorled at lower nodes; spikelets linear; spikelets not persistent on plant at maturity

E. tenuifolia

Primary panicle branches whorled at lower nodes; spikelets oblong; spikelets persistent on plant

E.tef

6(3). Panicle open; spikelets tough throughout; lower glume hyaline................................................. 7

Panicle contracted; spikelets fragile above; lower glume membranous.......................... E. sarmentosa

7(6). $\quad$ Primary panicle branches naked below; panicle branches bearded in axils; inflorescence exserted

E. pilosa

Primary panicle branches bearing spikelets almost to base; panicle branches glabrous in axils; inflorescence embraced at base by subtending leaf

E. aegyptiaca

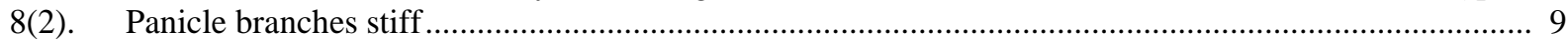

Panicle branches flexible ........................................................................................ E. tremula

Panicle branches capillary (capillary can be stiff or flexible - this does not work!) ................. E. aspera

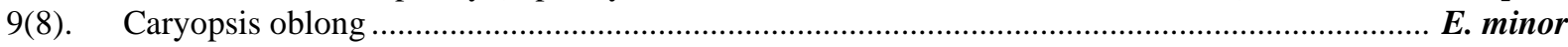

Caryopsis orbicular........................................................................................ E. cilianensis

10(2). Panicle branches flexible; panicle spiciform; glumes shorter than spikelet............................... E. ciliaris

Panicle branches capillary; panicle open; glumes as long as the spikelet............................... E. Iepida

\section{Discussion}

Liang (1997) mentioned that Poaceae systematics and evolutionary research face the following challenges as compared to other families: high number of species; floral and vegetative morphology are simple; character evolution that is both progressive and regressive, also known as bilateral character change, makes it difficult to establish a character's polarity during phylogenetic studies (Stebbins, 1987). Polyploidy and extensive hybridization that approximately $80 \%$ of the species investigated for chromosomal counts have experienced polyploidy at some point throughout their history. (De Wet, 1987); in addition, parallel evolution is common due to adaptation to similar environments and continuous evolution of various characters at different rates along similar conditions (Stebbins, 1956, 1987; Hilu \& Wright, 1982; Pohl, 1987).

At genus level; grass taxonomists have grappled for long time with Eragrostis categorization, (Ingram and Doyle, 2004). Lazarides (1997) mentioned that while leaf characteristics have little taxonomic relevance, the blade apices are occasionally diagnostic when used in combination with other leaf traits. Coloration can aid in identification; for example, the basal parts of Eragrostis tef are purplish, and the culmnodes in E. cilianensis are purple-black, and 


\section{Sami Rabei et al.}

the spikelets of E. cilianensis become a distinctive olive-green in colour at maturity.

Clayton (1974) and Clayton \& Renvoize (1986) have arrived, on the basis of disarticulation, that natural groups of Eragrostis can be recognized into four sections: Psilantha (K. Koch) Tsvelev, Eragrostis (World-wide), Lappula Stapf (Old World), and Platystachya Benth. \& Hook (confined to Africa). Based on 442 characteristics from 53 Eragrostis species and three closely related genera, Van den Borre and Watson (1994) developed an infrageneric classification, depending on 60 anatomical and 58 morphological traits, phenetic and cladistic techniques were used to examine the characteristics. The study recognized three subgenera: Eragrostis; Caesiae Van den Borre \& L. Watson. and Psilantha (K. Koch) L. Watson, the latter is characterized by a entirely disarticulating flowers and fragile rhachilla, was seen to a synonym under Eragrostis with its distinctive form of disarticulation. Lazarides (1997) recognized 6 infrageneric groups within Eragrostis depending mostly on the manner of spikelet disarticulation. However, the character of disarticulation, although highly diverse, it does not necessarily correspond to anatomical characteristics. Lazarides (l.c.) aligned the classification of Eragrostis with Van den Borre \& Watson (1994), who considered Eragrostis and Psilantha at the rank of subgenera. Cope (1998), in the Flora of Zambesiaca, delineated 9 informal species groups based on the spikelet characters as the morphology of lemma and palea, in addition to the spikelet disarticulation. Boechat \& Longhi-Wagner (2003) assigned the Eragrostis species that occur in Brazil into six groups depending on the morphology of the caryopsis. Within 26 species of Eragrostis from northern Mexico, Peterson \& Valdés Reyna (2005) distinguish four proposed lineages based on the total morphological characteristics.

The results of coordinate analysis as well as UPGMA dendrogram subdivided the studied Egyptian Eragrostis species into three groups: group A: characterized by long pedicels, lower glumes with distinct lateral veins (includes: E. minor and E. cilianensis); group B: characterized by filiform pedicel, lateral veins of lower and upper glumes absent (includes E. tef, E. tenuifolia, E. sarmentosa, E. barrelieri, E. aegyptiaca and E. pilosa), while group C: characterized by open panicle with capillary branches (includes the rest of the studied taxa). However, our results based on overall characters doesn't correlate with sections proposed by Clayton \& Renvoize, (1986) and Cope (1998) which are based on few characters (i.e., disarticulating of spikelets). The identification key constructed here is based mainly on morphological characters of Inflorescence, spikelets, panicle, glumes, palea keels and the shape of the caryopsis.

In addition to the above-mentioned species, Eragrostis purpurascens (Spreng.) Schult., a species native to Brazil and Uruguay was reported from Egypt by Rüppell (1822) without exact location (Specimen from, Herbarium senckenbergianum; https://www.gbif.org/occurrence/304611859 8); while Link (1827) described E. nitida from Nubia, south of Egypt. No specimens were encountered by the authors belonging to these taxa from Egypt. On the other hand, Täckholm et al. (1941) pointed out that E. multiflora Trin. (1841) is erroneously cited as synonym to E. cilianensis or to E. tremula, according to recent studies E. multiflora is another distinct species. However, many 


\section{Phenotypic Diversity of Eragrostis Wolf in Egypt.}

species have been introduced as fodder plants, and are probably no longer exist, more studies are needed to verify the presence of these taxa in Egypt.

\section{Acknowledgements:}

The authors are grateful to thanks Dr Maria Vorontsova (Royal Botanic Gardens, Kew, UK) for valuable information; Prof Dr. Mike Dallwitz (13 Warrambool Close, Giralang ACT 2617, Australia) for his help using DELTA and Intkey and Dr. Oyvind Hammer (Natural History Museum, University of Oslo) for his help using PAST program.

\section{References:}

Boechat, S. C. and Longhi-Wagner, H. M. (2003). Análise do fruto em espécies de Eragrostis Wolf (Poaceae). Iheringia 58: 131-166

Clayton, W. D. (1974). Eragrostis. In: Clayton, W.D., Phillips, S.M. and Renvoize, S.A. Gramineae (part 2), Flora of Tropical East Africa. A. A. Balkema, Rotterdam. Pp. 188-244

Clayton, W. D., and Renvoise, S. A. (1986). Genera Graminum, Grasses of the world. Kew Bull. Add. Ser. 13, 1-389.

Clayton, W.D., Vorontsova, M.S., Harman, K.T. and Williamson, H. (2021 onwards). GrassBase - The Online World Grass Flora. http://www.kew.org/data/grasses-db.html. [Retrieved 15 June 2021.

Colbry, V. l. (1957). Diagnostic characteristics of the fruits and florets of economic species of North American Sporobolus. Contr. U.S. Natl. Herb. 34: $1-24$

Coleman, CO., Lowry, JK. \& Macfarlane, T. (2010). DELTA for Beginners: An introduction into the taxonomy software package DELTA. ZooKeys, 45: 1-75.
Cope, T. A. (1998). A synopsis of Eragrostis Wolf (Poaceae) in the flora Zambesiaca area. Kew Bull. 53: 129-164.

Cope T. A. (2005). Gramineae in Boulos, L. Flora of Egypt vol. 4: pp. 124 - 349. AlHadara Publishing, Cairo, Egypt.

Cope, T. A. (2009). Gramineae in Boulos, L. 2009. Flora of Egypt checklist, revised annotated edition. Al Hadara publishing, Cairo, Egypt.

Cope, T. A. and Hosni, H. A. (1991). A key to Egyptian grasses. Royal Botanic Gardens, Kew and Cairo University Herbarium.

Dallwitz, M. J., Paine, T. A. \& Zurcher, E. J. (2000). User's guide to the DELTA system: A general system for processing taxonomic descriptions. 4, 12 ed. Canberra.

Dallwitz, M. J., Paine, T. A. and Zurcher, E. J. (2010). User's guide to the DELTA System: a general system for processing taxonomic descriptions. http://www.deltaintkey.com/www/uguide.htm [22 August 2020]

Dallwitz, M. J., Paine, T. A. and Zurcher, E. J. (2013). Principles of interactive keys. http://www.delta-

intkey.com/www/interactivekeys.htm [8 October 2018]

De Wet, J. M. J. (1987). Hybridization and polyploidy in the Poaceae In Soderstrom, T. R., Hilu, K. W., Campbell, C.S., and Barkworkth, M. A. [eds.], Grass systematics and evolution, 188-194. Smithsonian Institution Press, Washington, DC.

El Hadidi, M.N. 2000. Floa Aegyptiaca vol. 1. The Palm Press and Cairo University Herbarium

El Hadidi, M.N. and Fayed, A.A. (1994/95). Materials for Excursion Flora of Egypt. Taeckholmia 15: 194-195.

Gower, J.C. (1966). Some distance properties of latent root and vector methods used in multivariate analysis. Biometrika, 53: 325-38. 
Gower, J.C. (1971). A general coefficient of similarity and some of its properties. Biometrics 23: 623-637.

Gower, J.C. (1982). Euclidean distance geometry. Math. Sci. 7: 1-14

Hammer, $\varnothing$ and Harper, D.A.T. and Ryan, P.D. (2001). PAST: paleontological statistics software package for education and data analysis. Palaeontol Electron 4: http://palaeo-electronica.org/2001_ 1/past/issue1_01.htm

Hammer, Ø. And Harper, D.A.T. (2006). Paleontological data analysis. Blackwell, Oxford.

Hilu, K. W., and Wright, K. (1982). Systematics of Gramineae: A cluster analysis study. Taxon 31: 9-36.

Hssaini, L., Hanine, H., Razouk, R., Ennahli, S., Mekaoui, A., Ejjilani, A., \& Charafi, J. (2020). Assessment of genetic diversity in Moroccan fig (Ficus carica L.) collection by combining morphological and physicochemical descriptors. Genetic Resources and Crop Evolution,67(2), 457-474.

Ibrahim, K.; Hosni, H. A. and Peterson, P. (2016). Grasses of Egypt. Smithsonian Contributions to Botany 103: 1-201

Ingram, A. l. (2010). Evolution of leaf blade anatomy in Eragrostis (Poaceae). Syst. Bot. 35: 755-765.

Ingram, A. I. and Doyle, J. J. (2004). Is Eragrostis (Poaceae) monophyletic? Insights from nuclear and plastid sequence data. Syst. Bot. 29: 545-552.

Kamran, S., Khan, S. M., Ahmad, Z., Rahman, A. U., Iqbal, M., Manan, F., ... \& Ullah, S. (2020). The role of graveyards in species conservation and beta diversity: a vegetation appraisal of sacred habitats from Bannu, Pakistan. Journal of Forestry Research, 31(4), 1147-1158.

Lazarides, M. (1997). A revision of Eragrostis (Eragrostideae, Eleusininae, Poaceae) in Australia. Aust. Syst Bot 10, 77-187.
Liang, H. (1997). The Phylogenetic reconstruction of the grass family (Poaceae) using matK gene sequences, Virginia Polytechnic Institute and State University.

Link, H.F. (1827). Hortus Regius Botanicus Berolinensis vol. 1. Berolini, apud G. Reimer.

López-Palacios, C., Reyes-Agüero, J. A., Peña-Valdivia, C. B., \& Aguirre-Rivera, J. R. (2019). Physical characteristics of fruits and seeds of Opuntia sp. as evidence of changes through domestication in the Southern Mexican Plateau. Genetic Resources and Crop Evolution, 66(2), 349-362.

Muhammad, S., Malik, S. M., Khan, Z. U. D., Tayyab, M., Sardar, A. A., Zahid, M., \& Akram, N. (2021). Two-way indicator species analysis of weed species of potato and wheat in crop fields of Sharqpur Tehsil, Pakistan. Bangladesh Journal of Plant Taxonomy, 28(1), 233240.

Mulumba, J. W., \& Kakudidi, E. (2010). Numerical taxonomic study of Acacia senegal (Fabaceae) in the cattle corridor of Uganda. South African Journal of Botany, 76(2), 272-278.

Peterson, P. M. and Sánchez Vega, I. (2007). Eragrostis (Poaceae: Chloridoideae: Eragrostideae: Eragrostidinae) of Peru. Ann. Missouri Bot. Gard. 94: 745-790.

Peterson, P. M., ColuMbus, J. T. and Pennington, S. J. (2007). Classification and biogeography of New World grasses: Chloridoideae. Aliso 23: 580-594.

Peterson, P. M., Romaschenko, k. and Johnson, G. (2010). A classification of the Chloridoideae (Poaceae) based on multi-gene phylogenetic trees. Mol. Phylogenet. Evol. 55: 580-598.

Peterson, P. M. and ValDés Reyna, J. (2005). Eragrostis (Poaceae: Chloridoideae: Eragrostideae: 
Eragrostidinae) from northeastern Mexico. Sida 21: 1365-1420.

Peterson, P. M., Webster, R. D. and ValDés Reyna, J. (1997). Genera of the New World Eragrostideae (Poaceae: Chloridoideae). Smithsonian Contr. Bot. 87: 1-50.

Pohl, R. W. (1987). Man and the grasses: a history. In Soderstrom, T. R., Hilu, K. W., Campbell, C.S., and Barkworkth, M. A. [eds.], Grass systematics and evolution, 355-358. Smithsonian Institution Press, Washington, DC.

POWO (2021a). "Plants of the World Online. Facilitated by the Royal Botanic Gardens, Kew. Published on the Internet; http://www.plantsoftheworldonline.org/ Retrieved 2906 2021."

POWO (2021b).

http://powo.science.kew.org/taxon/urn:lsi d:ipni.org:names:300006282\#distribution-map/ Retrieved 29 June 2021

Rabei, S. (2011). A morphological, anatomical and taxonomic study of Umbelliferae in Egypt. LAP Lambert, Köln.

Rabei, S. and El-Gazzar, A. (2007). Computer-generated Keys to Species of Hyptis s.l. (Labiatae). Taeckholmia 27: 1139.

Rabei, S. and Abdel Khalik K. A. (2012). Conventional keys for Convolvulaceae in the flora of Egypt. Fl. Medit. 22: 45-62.

Rabei, S., Rizk, R. M., \& Khedr, A. H. A. (2013). Keys for and morphological character variation in some Egyptian cultivars of Cucurbitaceae. Genetic Resources and Crop Evolution, 60 (4): 1353-1364

Rahman, M.Z. and Rahman, M.O. (2012). A morphometric analysis of Desmodium Desv. (Fabaceae) in Bangladesh. Bangladesh J. Bot., 41(2): 143-148.
Sneath, P.H.A. and R.R. Sokal, (1973). Numerical Taxonomy: The Principles and Practice of Numerical Classification. $2^{\text {nd }}$ Ed., WH Freeman and Co., San Francisco, CA., USA., pp: 573.

Stebbins, G. L. (1956). Cytogenetics and evolution of the grass family. Amer. Jour. Bot. 43: 890-905.

Stebbins, G. L. (1987). Grass systematics and evolution: past, present and future. In Soderstrom, T. R., Hilu, K. W., Campbell, C.S., and Barkworkth, M. A. [eds.], Grass systematics and evolution, 359-367. Smithsonian Institution Press, Washington, DC.

Täckholm, V., (1974). Students' Flora of Egypt. Ed. 2. Beirut.

Täckholm, G.; V. and Drar, M. (1941). Flora of Egypt. Vol.1. Bull. Fac.Sci. Fouad I Univ. no. 17: 185 - 196.

Terrell, E. E. and Peterson, P. M. (1993). Caryopsis morphology and classification in the Triticeae (Pooideae: Poaceae). Smithsonian Contr. Bot. 83: 1-25

Van den Borre, A. and Watson, L. (1994). The infrageneric classification of Eragrostis (Poaceae). Taxon 43: 383-422.

Veldkamp, J.F. (2002). Revision of Eragrostis (Gramineae, Chloridoideae) in Malesia. Blumea 47: 157-204.

Watson, L., Macfarlane, T.D., and Dallwitz, M.J. (1992 onwards). The grass genera of the world: descriptions, illustrations, identification, and information retrieval; including synonyms, morphology, anatomy, physiology, phytochemistry, cytology, classification, pathogens, world and local distribution, and references. Version: 15 June 2021. delta-intkey.com'.

Zuur A.F., Ieno E.N., Smith G.M. (2007). Analysing ecological data. Statistics for biology and health. Springer, New York, 672pp. 


\section{Sami Rabei et al.}

Appendix 1. List of studied species Eragrostis arranged alphabetically (All specimens are kept in Cairo University Herbarium (CAI). Phytogeographical regions after El Hadidi (2000)

\section{1- Eragrostis aegyptiaca (Willd.) Delile}

Nv: Barrage, 8.1960; L.Boulos s.n. - Mahmoudia, Behira, 18.7.1989; A.Amer 12617 - Gezeira, 19.11.1926; G.Täckholm s.n. - N of Giza pyramids, 5.11.1952 ; G.Täckholm s.n.. Nn: Near Gebel Silsila, Kom Ombo, 5.3.1961; V. Täckholm et al. s.n. - Luxor, 18.4.1934; G.Runkewitz s.n. - Abu Simbel, 25.3.1968, V.Täckholm s.n. - Abu simbel, 5.3.1975; N. El Hadidi s.n. - Aswan, E of Cataract, 16.1.1927; G.Täckholm s.n. - Aswan, Siheil Islands, 17.1.1927; G.Täckholm s.n. Aswan Dam, 8.12.1964; L.Boulos s.n. - Aswan, Shallal, 17.21.1927; G.Täckholm s.n. - Plant Island, Aswan, 15.1.1963; V.Täckholm et al. s.n. - Lake Naser, 25.2.1985; M.Ali 4468 -Ballana, 5.2.1964; L.Boulos s.n. - Aniba, 14-18.11.1963; L.Boulos s.n. Ol: Qara Oasis, 17.1.1927; G.Täckholm s.n.

\section{2- Eragrostis aspera (Jacq.) Nees}

Ge: Gebel Elba, 23-27.1.1929; G.Täckholm s,n, - Wadi Aidieb, 20.1.1962; V.Täckholm et al. 35 - Wadi Kansisrob, 23-27.1.1929; G.Täckholm s.n. - Bir Kansisrob, 3.2.1962; V.Täckholm et al. s.n. - Wadi Shalal, 24.1.1962; V.Täckholm et al. 573 - Gorge across the NE slope of Gebel Elba, 21.1.1962; V.Täckholm et al. 183.

\section{3- Eragrostis barrelieri Daveau}

Mm: Burg El Arab, 24.9.1971; M.Imam et al. s.n. - Maamoura, 26.8.1967; N.El Hadidi s.n. Rafah, 13.8.1993; I. El Garf s.n. - Nv: Barrage,18.10.1985; N.El Hadidi s.n. - Khanka, 20.7.1929; M.Hassib s.n. - Between Khanka and Abu Zaabal, 31.12.1926; G.Täckholm s.n. - Ismailia, 26.8.1982; A.Amer 597 - Tahrir province, 21.9.1967; N. El Hadidi, M.Mahdi, I.El Sayed s.n. Wadi Digal, near Maadi, 3.9.1966; N.El Hadidi, M.Imam s.n. - Cairo, Zaafran palace, 27.7.1929; M.Hassib s.n. - Mahmoudia, Behera, 25.4.1987; A.Amer 10230 - Wadi el Natroun, kafr Dawoud, 18.7.1968; N. El Hadidi s.n. - Wadi El Natroun, 27.2.1969; S. Ghabour s.n. - Matay, Minya, 5.2.1980; A.Amry; 1174. Nn: Abu Simbel, 4.2.1963; V.Täckholm et al. s.n. - Nagaa El Qasab, Abu Simbel, 26.12.1963; L. Boulos s.n. - Aniba, 14-18.11.1963; V.Täckholm, L.Boulos, M.Zahran s.n. - N.Qostul, 29.12.1963; L.Boulos s.n. - N Ballana, 2.1.1964; L. Boulos s.n. - Dl: Cairo Alexandria Desert rd., 31.5.1964; V.Täckholm s.n. -166 km from Cairo on Desert rd., 7.7.1976; A.Amin, A.Soliman, S.Sisi s.n. - S: 22 kmSt.Catherine- Feiran rd. 18.8.1982; El Hadidi et al. s.n. - Wadi El Arbaien , St. Catherine, 19.8.1982; N. El Hadidi et al. s.n. - R: Wadi Gemal, RSC, 6.2.1961; V.Täckholm et al 287 - On: Kharga, 15.8.1967; N. El Hadidi s.n. - Ge: Gebel Elba, 23-27.1.1929; G.Täckholm s.n.

\section{4- $\boldsymbol{E}$. cilianensis (All.) Vignolo ex Janch.}

Mm: Maamoura, Alexandria, 26.8.1967;Alexandria, Nouzha, 9.10.1907; G.Schweinfurth s.n. - N. El Hadidi s.n. - El Arish, 15.8.1951; V.Täckholm et al. s.n. - Nv: Giza, 15.5.1971; J.Kosinova s.n. - Barrage, 7.1.1927; G.Täckholm s.n. - Wadi El Natroun, 18.7.2009; A.Badr s.n. - Abu El Matamir, Beheira, 26.4.1982; A.Amer 10680-Beni Suef, 8.8.1952; M.Imam s.n. - Fayium, 22.4.1958; V.Täckholm s.n. -Abu Qurqas, Menya, 15.12.1979; A.Amry 1094 - Edfu, 29.6.1967; N.El Hadidi, S.Ghabour s.n. - Al Wasta, 16.10.1971; L.Boulos, M.Imam, M.Mahdi s.n.. Nn: Aswan, 11.1.1909; G.Runkewitz s.n. - Luxor, 28.2.1933; G.Runkewitz s.n. - Abu Simbel, 4.2. 1963; V.Täckholm et al. 197 - Aswan, 7.12.1964; L.Boulos s.n. - Nubia, 1924; J.Shabetai s.n. - Ballana, 6.1.1964; 


\section{Phenotypic Diversity of Eragrostis Wolf in Egypt.}

L.Boulos s.n. - Ol: Bahariya, Al Agouz, 6.6.1979; M.AbdelGhani 1953 - Bahariya, El Qasr, 12.9.1971; M.Imam et al s.n.. On: Kharga, 5.12.1966; N. El Hadidi s.n. - Kharga-Baris rd., 13.3.1976; N.El Hadidi s.n. -. Dg: Ismailia, 18.3.1927; G.Täckholm s.n. - Cairo-Ismailia rd., 30.7.1982; Ismailia, 11.8.1983; A.Amer 4732 - A.El Bakry s.n. - Ge: Wadi Aideib, 20.1.1962; V.Täckholm et al. 84 - Wadi Yahameib, 22.1.1962; V.Täckholm et al. 272 - Wadi Kansisrob, 2327.1. 1929; G.Täckholm s.n. - Gebel Alafoot, 7.2.1962; V.Täckholm et al. 1675 - Wadi Haiteem,. 27.1.1962; V.Täckholm et al. s.n. - Wadi Oolak, 22.1.1962; V.Täckholm et al. 693 - Ra: Mersa Halaib, 21.1.1929; G.Täckholm s.n. - Gebel Hamata, 7.2.1961; V.Täckholm et al. 390 - Wadi Gamal, 6.2.1961; V.Täckholm et al. s.n.

5- E. ciliaris (L.) R.Br.

Ge: Wadi yahameib, 22.1.1962; V.Täckholm et al. 253 - Wadi Adel Dieb, 4.2.1962; V.Täckholm et al 1417 - Wadi Seramatai, 7.2.1962; V.Täckholm et al. s.n. - Wadi seramatai, 29.1.1962 ; V.Täckholm et al. 1107 - Wadi Akwamtra, 19.2.1965; J.Osborn \& I.Helmy s.n. - Wadi Kansisrob, 17.2.1967; J.Osborn \& I.Helmy s.n. - Wadi Lasitiet, 7.2.1962; V.Täckholm 1701 - Wadi El Khina, 5.2.1962; 5.2.1962; V.Täckholm et al. s.n. Ra: Khor Gebel El Faraid, 12.2.1961; V.Täckholm et al. 1107 - N Abu Ramad, 20.1.1962; V.Täckholm et al. 8 - Gebel Hamata, 7.2.1961; V.Täckholm et al. 341 - Suakin El Qadim, 5.2.1962; V.Täckholm et al. 1564 - Mersa Kolies, 4.2.1962; V.Täckholm et al. 1353 - Mersa Abu Naam, 25.1.1962; V.Täckholm et al. s.n. - Mersa Sanadiai, 5.2.1962; V.Täckholm ert al s.n. - Mersa Halaib, 20.1.1929; G.Täckholm s.n.

6- E. japonica (Thunb.) Trin.

Nn: Kom Ombo, 20.1.1927; G.Täckholm s.n. - Ballana, 30.12.1963; L.Boulos s.n. - Aswan, 20.11.1963; L.Boulos s.n. - Aswan, Cararact, 16.1.1926; G.Täckholm s.n. - Aswan, Gebel Silsila, 11.2.1964; V.Täckholm s.n.

7- E. lepida (A.Rich.) Hochst. ex Steud.

Ge: Gebel Elba, 23-27.1.1929; G.Täckholm s.n. - Gebel Mekerba, 23.1.1962; V.Täckholm et al s.n. - Wadi Shallal, 24.1.1962; V.Täckholm et al. s.n. - Bir Akwamtra, 14.2.1967; J.Osborn \& I. Helmy s.n. - Wadi Kansisrob, 23-27.1.1929; G.Täckholm s.n.

\section{8- E. minor Host}

S: Wadi Talah, 8.10.1983; N.El Hadidi s.n. - Nv: Itsa, Mahmoudia, 9.9.19982: M. Adel Ghani 3765.

\section{9- E. pilosa (L.) P.Beauv.}

Mm: Amria, near Alexandria,20.8.1971; M.Imam, I.Ibrahim, M.Mahdi s.n. -Nubaria, 12.6.1969; N.el Hadidi s.n. - Nv: Delingat, Behira, 17.8.1987; A.Amer 12434 - Khanka, 31.12.1926; G.Täckholm s.n. - Ismailia, 10.8.1981; A.Amer 52 - Barrage, 7.1.1927; G.Täckholm s.n. - Maadi, 5.12.1926; G.Täckholm s.n. - Giza, 27.10.1910; E.Hartmann s.n. - Fayium, Tamiya, 11.11.1982; M.Abdelghani 4532 - Belbis, 10.9.1966; A.Amin, L.Boulos, M.Mahdi s.n. -Minya, Samalout, 15.12.1979; M.Amry 1132 - Assuit, 17.10.1971; M.Imam, L.boulos, M.Mahdi s.n. Nn: Kom Ombo, 20.1.1927; G.Täckholm s.n. - Abu Simbel, 5.3.1975; N.El Hadidi s.n. - Abu Simbel, 4.1. 1964; L.Boulos s.n. - Aswan, 17.1.1927; G.Täckholm s.n. -On: Kharga Oasis, 30.3.1963; L.Boulos s.n. - Dl: Cairo Alexandria Desert rd., 7.7.1976; A.Amin, A.Soliman, S.Sisi s.n. - 


\section{Sami Rabei et al.}

10- E. sarmentosa (Thunb.) Trin.

Zimbabwe, s.d.; S.Laeguard 15920

11- E. tremula

Senegal, Dakar, 29.10.1948; s.col.

12- E. tef (Zuccagni) Trotter

Nv: Behera, Kom El Hanash, 15.10.1909; G.Maire s.n. Ol: Bahariya, El Gedida, 2.10.1978. M.AdeGhani 958 -

13- Eragrostis tenella (L.) P.Beauv. ex Roem. \& Schult.

Kenya, Mombasa, 6.4.1972; Persoon 2283 - Sudan, Erkuit, 9.3.1938; M.Drar s.n. - Asir, Hedjaz, 3.1992; A.Hegazi s.n.

14- E. tenuifolia (A.Rich.) Hochst. ex Steud.

Nv: Giza, 19.7.1976; S.Sisi s.n. 